\title{
APPLICATION OF NUCLEAR ANALYTICAL TECHNIQUES IN CHARACTERIZATION OF SEVERAL SAMPLE MATRICES
}

\author{
APLIKASI TEKNIK ANALISIS NUKLIR DALAM KARAKTERISASI \\ BERBAGAI MATRIKS SAMPEL
}

\author{
D. D. Lestiani ${ }^{1}$, M Santoso ${ }^{1}$, S. Kurniawati ${ }^{1}$, E. Damastuti ${ }^{1}$, N. Adventini ${ }^{1}$, \\ D. K. Sari ${ }^{1}$, and I. Kusmartini ${ }^{1}$ \\ ${ }^{1}$ Center for Applied Nuclear Science and Technology - National Nuclear Energy Agency (BATAN), Jln \\ Tamansari 71, Bandung, Indonesia, 022-250-3997, e-mail: diahdwi@batan.go.id
}

Diterima tanggal 02 April 2020, disetujui tanggal 23 April 2020

\begin{abstract}
The existence of elements in major, minor, and even in trace levels could have a significant impact on human health, environmental, industry, or other life sciences. Results of characterization from several matrices of samples could become as valuable and important information since a lot of important decisions regarding public health, environmental protection, and international trade is based on those results. Characterization of several matrices of samples requires excellence, reliable, and complies with ideal criteria as an analytical method. In recent years, nuclear analytical techniques become one of the analytical techniques that could meet the challenge of capability in characterization various matrices of samples and have been proven to be suitable and applicable in a broad range of applications. Nuclear analytical techniques deal with nuclear excitations, electron inner-shell excitations, nuclear reactions, and/or nuclear decay. These techniques are selective with high sensitivity, non-destructive, simultaneous, and limit detection microgram until nanogram level. In this paper, the role and contribution of nuclear analytical techniques used for BATAN research, especially neutron activation analysis (NAA), particleinduced X-ray emission (PIXE), and X-ray Fluorescence (XRF) in the characterization of various matrices of geological, pharmacy, biology and environmental samples were discussed. The comparison with other methods was also carried out. The validations of results were conducted by analysis of standard reference material (SRM). Discussion related optimization of parameter measurement and similar efforts were also presented. The results of this research are hopefully could show and emphasize the significant role of NAT in the characterization of several matrices of samples in contribution and support the life sciences and public welfare.
\end{abstract}

Keywords: Nuclear analytical techniques, NAA, PIXE, XRF, geological, environmental.

\begin{abstract}
ABSTRAK
Eksistensi unsur-unsur yang berada dalam jumlah mayor, minor, dan bahkan dalam jumlah trace, dapat memiliki dampak signifikan dalam kesehatan manusia, lingkungan, industri, atau bidang kehidupan lainnya. Hasil karakterisasi dari beberapa matriks sampel dapat menjadi informasi yang berharga dan penting karena banyak keputusan penting mengenai kesehatan masyarakat, perlindungan lingkungan dan perdagangan internasional didasarkan pada hasil tersebut. Karakterisasi beberapa matriks sampel membutuhkan teknik yang unggul, dapat diandalkan, dan memenuhi kriteria ideal sebagai metode analisis. Dalam beberapa tahun terakhir, teknik analisis nuklir menjadi salah satu teknik analisis yang dapat memenuhi tantangan dalam kemampuan karakterisasi berbagai matriks sampel dan telah terbukti sesuai dan dapat diterapkan dalam berbagai aplikasi. Teknik analisis nuklir berhubungan dengan eksitasi nuklir, rangsangan kulit dalam elektron, reaksi nuklir, dan/atau peluruhan nuklir. Teknik-teknik ini selektif dengan sensitivitas tinggi, non-destruktif, simultan, dan limit deteksi mikrogram hingga tingkat nanogram. Dalam makalah ini, dibahas peran dan kontribusi teknik analisis nuklir yang digunakan untuk penelitian BATAN terutama Neutron Activation Analysis (NAA), Particle Induced X-Ray Emission (PIXE) dan X-Ray Fluorescence (XRF) dalam karakterisasi berbagai matriks geologi, sampel farmasi, biologi dan lingkungan. Perbandingan dengan metode lain juga dilakukan. Validasi dilakukan dengan analisis bahan acuan standar Standard Reference Material (SRM). Diskusi terkait optimasi pengukuran parameter dan upaya terkaitjuga
\end{abstract}


disajikan. Hasil penelitian ini diharapkan dapat menunjukkan dan menekankan peran signifikan teknik analisis nuklir (TAN) dalam karakterisasi beberapa matriks sampel dalam kontribusi dan mendukung ilmu kehidupan dan kesejahteraan masyarakat.

Kata kunci: Teknik analisik nuklir, AAN, PIXE, XRF, geologi, lingkungan.

\section{INTRODUCTION}

Research related to the analysis and development of the capability in the characterization of various elements accurately and validly is needed to support various government programs such as food security, advanced materials, nutrition, environment, health, and medicine programs [1-13]. Various problems related to the need for information on the composition characteristics of multiple elements in the sample demanded comprehensive research in the development of analytical methods and application of analytical techniques for identification. This characterization step is a start in the study and development of further research in the fields of industry, agriculture, mining, advanced materials, food, health, and the environment, which need supporting tools in optimizing related research [1-13]. Various sample matrices such as food, health (such as medicines, organs, human body tissue, serum, hair, and so on), environment (such as soil, air, water, sediment), geology, industry, materials, and other samples generally contain various kinds of elements both major, minor and trace $[4,6-8,14]$.

The existence of an element, even at very low levels of trace, can have a very significant impact on human health, the environment, or industry. In biomedical science, it is known that there is a correlation between deficiency or excess of certain elements with symptoms of health problems ]15-17]. Lack of micronutrients in food as the body's intake also impacts its function as a metalloenzyme in the process of biochemical reactions and metabolic systems $[18,19]$. In the field of environment, the elements contained in environmental samples generally can provide an overview of the level of toxicity and quality of the environment and can be used as a key element in identifying sources of pollutants [3,20]. The element concentration assessment in the environmental sample matrix can be used to review compliance with environmental regulations or quality standards (generally below 10-10 g/g) [21]. The concentration of an element in the environment can also be an early warning of the level of exposure received by the community. Therefore it can be used as a scientific-based foundation in making appropriate and directed policies in an effort to improve environmental quality, health problems, and greater financial losses can be avoided. In the industrial sector, identification of elements as impurities (generally at the level of 10-12 g/g) in an industrial product, especially advanced materials, is needed in determining the quality, designation, and selling price of these. Of these various needs, comprehensive research in developing analytical methods and application of analytical techniques for the identification of elements in various sample matrices is needed.

In the 19th century, when various analytical methods for characterization of samples were developed, many elements in various sample matrices were not detected, especially elements at the minor and trace levels. Along with technological advances and characterization capabilities, trace elements and even ultra-trace can be detected properly. BATAN is expected to 
contribute significantly to solving national problems by prioritizing the application and implementation of nuclear-based technology. The nuclear analytical technique is one of the analytical techniques that have the prospect of increasing characterization capabilities on various sample matrices. The nuclear analytical technique (NAT) is an accurate, sensitive, non-destructive, multi-elemental analysis technique capable of detecting in micro order to nanogram [22,23]. In this context, BATAN Bandung, through research activities related to the application of nuclear analysis techniques, has carried out various applications that prioritize the advantages of nuclear analysis techniques as a solution to overcome the limitations of conventional analytical techniques and promote independence in the analysis.

NAT nuclear analytical technique is defined as an analytical technique related to the principles of core excitation, electron excitation, nuclear reactions, and/ or radioactive decay. NAT can include analytical techniques such as Neutron Activation Analysis (NAA), ion beam analysis - Particles Induced X-ray Emission (PIXE), and X-Ray Fluorescence (XRF) (21-23). These techniques are a very selective elemental analysis technique with high sensitivity, non-destructive, simultaneous, and has a limit of detection reaching the order of micrograms and even nanograms. One of the capabilities shown by the PIXE technique is characterization using this technique can analyze the number of samples up to hundreds of samples per day and only requires a small sample weight of $\sim 100 \mu \mathrm{g}$. This reason makes nuclear technique as an analysis technique that is worth considering for the analysis of various sample matrices compared to conventional analysis techniques. Cahill, 1990 stated that almost $90 \%$ of air particulate filter samples in North America were analyzed using nuclear techniques. Even in Australia in the last four years, more than 9000 filter samples have been analyzed using nuclear techniques, specifically PIXE [24].

This paper aims to introduce the application of nuclear analytical techniques, especially NAA, PIXE, and XRF, on the characterization of various sample matrices by optimizing various parameters. It includes quality assurance of test results in the form of validation methods using a variety of standard reference materials (SRM) or comparison with other methods to show that NAT has the superior and reliable ability in characterizing various sample matrices.

\section{METHODS}

\section{Neutron Activation Analysis}

Neutron activation analysis (NAA) is an analytical method for the qualitative and quantitative determination of elements based on the measurement of the gamma-ray radiation characteristic of radionuclides that are formed directly or indirectly through the process of neutron irradiation on a material. The elemental concentrations are calculated by the comparative method [23]. Samples are irradiated with neutrons in reactors or accelerators. Nuclides that are stable in the sample (the target of the nucleus) will experience a neutron capture reaction, thus forming a radioactive nucleus (compound nucleus). In general, these radioactive nuclides will undergo decay through beta and gamma emission. After the sample is taken out from the reactor, the sample will emit radiation as a radioactive decay process. High-resolution spectrometers are used to detect delayed gamma rays. The irradiation of the sample depends on the neutron flux and the half-life of the radionuclides to be analyzed $[25,26]$. The detailed related NAA and the experimental preparation, as well as the quantitative and qualitative analysis, were described else [23]. Table 1 showed the list of radionuclides that generally detected in NAA. 


\section{Neutron Activation Analysis}

PIXE is one analysis technique that utilizes an ion beam (ion beam analysis IBA). This technique has a basic working principle in the form of interaction between accelerated particles (particle beam) with the material. Charged particles that are accelerated using an accelerator, when interacting with the material, will interact with electrons and atomic nuclei, exciting electrons from the deepest atomic shell. Electron excitation (generally $\mathrm{K}$ or $\mathrm{L}$ shells) will cause electron expelled, and the configuration becomes instability so that electrons from the outer shell will move to fill this hole, which will release excess energy when displaced in the form of X-rays [27]. This X-ray energy is characteristic for each element, so it can be used to identify certain elements contained in the material or material being analyzed $[24,27,28]$. The area of the peak of the X-ray in the spectrum produced is proportional to the number of atoms contained in the sample. This is used to determine the concentration of an element through comparison with known standards. The detailed of experimental preparation and measurement is written elsewhere [24,27,28].

\section{X-Ray Fluorescence}

The principle of measurement using $\mathrm{XRF}$ is the same as the principle in PIXE. It is based on the event of electron excitation when an atom in an element is bombarded or interacts with X-rays. Following the Pauli principle, the electron-hole will then be filled by electrons coming from outside orbitals and, at the same time, will always be accompanied by the release of X-rays that are characteristic for each element $[29,30]$. In qualitative analysis, XRF method can identify elements from the atomic number $(Z)=4$, namely Be to $Z=92(U)$ and has a measurement range from $\mu \mathrm{g} / \mathrm{g}$ to $\%$, and the detection limit at the level of $\mu \mathrm{g} / \mathrm{g}$ without preconcentration. Although Inductively Couple Plasma (ICP), Atomic Absorption Spectrophotometry (AAS), Neutron

Table 1. List of radionuclides that can be detected well by NAA[23,25,26]

\begin{tabular}{cccc}
\hline Element & Nuclide & Half life & Energy (keV) \\
\hline $\mathrm{Al}$ & ${ }^{28} \mathrm{Al}$ & $2.24 \mathrm{~m}$ & 1778.9 \\
$\mathrm{As}$ & ${ }^{76} \mathrm{As}$ & $26.3 \mathrm{~h}$ & 559.1 \\
$\mathrm{Ca}$ & ${ }^{49} \mathrm{Ca}$ & $8.7 \mathrm{~m}$ & 3084.4 \\
$\mathrm{Ce}$ & ${ }^{141} \mathrm{Ce}$ & $32.5 \mathrm{~d}$ & 145.4 \\
$\mathrm{Co}$ & ${ }^{60} \mathrm{Co}$ & $5.27 \mathrm{y}$ & $1173.2 ; 1332.4$ \\
$\mathrm{Cr}$ & ${ }^{51} \mathrm{Cr}$ & $27.72 \mathrm{~d}$ & 320 \\
$\mathrm{Cs}$ & ${ }^{134} \mathrm{Cs}$ & $2.06 \mathrm{y}$ & 795.8 \\
$\mathrm{Fe}$ & ${ }^{59} \mathrm{Fe}$ & $44.5 \mathrm{~d}$ & 1099.2 \\
$\mathrm{Hf}$ & ${ }^{181} \mathrm{Hf}$ & $42.4 \mathrm{~d}$ & 482.2 \\
$\mathrm{Hg}$ & ${ }^{203} \mathrm{Hg}$ & $46.6 \mathrm{~d}$ & 279.2 \\
$\mathrm{~K}$ & ${ }^{42} \mathrm{~K}$ & $12.36 \mathrm{~h}$ & 1524.7 \\
$\mathrm{La}$ & ${ }^{140} \mathrm{La}$ & $40.23 \mathrm{~h}$ & 1596.2 \\
$\mathrm{Mg}$ & ${ }^{27} \mathrm{Mg}$ & $9.45 \mathrm{~m}$ & $843.7 ; 1014.4$ \\
$\mathrm{Mn}$ & ${ }^{56} \mathrm{Mn}$ & $2.58 \mathrm{~h}$ & $846.7 ; 1810.7$ \\
$\mathrm{Na}$ & ${ }^{24} \mathrm{Na}$ & $15.02 \mathrm{~h}$ & $1368.6 ; 2754.1$ \\
$\mathrm{Sb}$ & ${ }^{124} \mathrm{Sb}$ & $60.2 \mathrm{~d}$ & 1691 \\
$\mathrm{Se}$ & ${ }^{75} \mathrm{Se}$ & $119.8 \mathrm{~d}$ & $264.7 ; 279.5$ \\
$\mathrm{Sm}$ & ${ }^{153} \mathrm{Sm}$ & $46.7 \mathrm{~h}$ & 103.2 \\
$\mathrm{Sc}$ & ${ }^{46} \mathrm{Sc}$ & $83,8 \mathrm{~d}$ & 889,$3 ; 1120,5$ \\
$\mathrm{Th}$ & ${ }^{233} \mathrm{~Pa}$ & $27 \mathrm{~d}$ & 311,9 \\
$\mathrm{Ti}$ & ${ }^{51} \mathrm{Ti}$ & $5,8 \mathrm{~m}$ & 320,1 \\
$\mathrm{U}$ & ${ }^{239} \mathrm{~Np}$ & $23,5 \mathrm{~d}$ & 74,$7 ; 277,7$ \\
$\mathrm{~V}$ & ${ }^{52} \mathrm{~V}$ & $3,76 \mathrm{~m}$ & 1434,1 \\
$\mathrm{Zn}$ & ${ }^{65} \mathrm{Zn}$ & $243,8 \mathrm{~d}$ & 1115,5 \\
& & $\mathrm{~m} / \mathrm{minute} ; \mathrm{h} / \mathrm{hour}, \mathrm{d} / \mathrm{day}, \mathrm{y} / \mathrm{year}$ &
\end{tabular}


Activation Analysis (NAA) and various mass spectrometry have much lower detection limits, the broad range of measurement is a unique characteristic of XRF. This XRF method can measure $\mathrm{Pb}, \mathrm{Cd}$, and $\mathrm{S}$ which cannot/are difficult to determine with NAA. If the two methods (NAA and XRF) are combined, it will produce extraordinary characterization capabilities.

These nuclear analytical techniques that will be applied in characterizing various sample matrices have various advantages and limitations. A comparative resume of these three methods with other methods is summarized in Table 2.

\section{Geological samples (zircon sand and iron sand)}

Zircon sand is a natural material that contains natural radioactive elements; this sand is suspected of having uranium and thorium content, which is quite large (in the order of ppm) if it is mined in a certain amount. Likewise, iron sand, which is suspected of having a quite large amount of $\mathrm{U}$ and $\mathrm{Th}$. Therefore, it is necessary to know the concentration of uranium and thorium in the sand quantitatively. Besides that, the elements of $\mathrm{Al}, \mathrm{Fe}$, Ti, $\mathrm{Na}, \mathrm{Zr}$, and $\mathrm{Hf}$ are also determined. Zircon sand and iron sand that have been dried and homogenized were taken $25 \mathrm{mg}$ each, then put into polyethylene vials for short irradiation, medium irradiation, and long irradiation [32]. The sand samples in the vial are then ready to be irradiated by neutrons in the Siwabessy Multipurpose Reactor (RSG), Serpong. For measurement of $\mathrm{Al}$ and $\mathrm{Ti}$ concentrations, samples were irradiated for 1 minute; for measurements of elements with medium half-life such as elements $\mathrm{U}$ and $\mathrm{Na}$ samples are irradiated for 15 minutes; while for measurement of Th and other elements of long half-life ( $\mathrm{Hf}, \mathrm{Zr}$, etc.) samples are irradiated for 2 hours. Neutron irradiation of the zircon sand sample causes ${ }^{238} \mathrm{U}$ and ${ }^{232} \mathrm{Th}$ nuclides contained in the sample to be activated into new radionuclides with the following reaction equation:

$$
\begin{aligned}
& { }^{238} \mathrm{U}+\mathrm{n} \rightarrow{ }^{239} \mathrm{U} \rightarrow{ }^{239} \mathrm{~Np} \\
& { }^{232} \mathrm{Th}+\mathrm{n} \rightarrow{ }^{233} \mathrm{Th} \rightarrow{ }^{233} \mathrm{~Pa}
\end{aligned}
$$

$\mathrm{U}$ and Th measurements are carried out using $\mathrm{Np}$ and $\mathrm{Pa}$ respectively, because after some time cooling $\mathrm{U}$ and Th decays into $\mathrm{Np}$ and $\mathrm{Pa}$ respectively [33].

\section{Pharmaceutical samples (supplements)}

In this study, elemental analysis was carried out on a supplement sample, spirulina, which is widely used as an additional source

\begin{tabular}{|c|c|c|c|c|c|}
\hline & NAA & PIXE & XRF & $\begin{array}{c}\text { ICP/MS/ } \\
\text { AES }\end{array}$ & AAS \\
\hline Multi-elemental & Yes & Yes & Yes & Yes & No \\
\hline Accuracy & Very Good & Fair & Fair & Good & Good \\
\hline Limit detection & $0.001-30 \mathrm{ng} / \mathrm{m}^{3}$ & $1-12 \mathrm{ng} / \mathrm{m}^{3}$ & $0.5-5 \mathrm{ng} / \mathrm{m}^{3}$ & $0.02-60 \mathrm{ng} / \mathrm{m}^{3}$ & $\begin{array}{c}0.001-40 \\
\mathrm{ng} / \mathrm{m}^{3}\end{array}$ \\
\hline Matrices effect & Little & Yes & Yes & Little & Rare \\
\hline $\begin{array}{c}\text { Sample } \\
\text { preparation }\end{array}$ & Simple & Very simple & Very simple & Digestion & Digestion \\
\hline Cost & High & High & Medium & Medium - High & Medium \\
\hline
\end{tabular}

Table 2. Comparison of nuclear analytical techniques and others $[21,22,24,31]$ 
of vitamins. Spirulina is a kind of aquatic algae that is bluish green. Spirulina is one of the platensis species; it is safe to consume and has high nutritional value, including $\mathrm{Fe}$ and $\mathrm{Zn}$, which are needed in the physiological processes of living things to help enzymes work and organ formation. In this paper, the discussion will be focused on the elements of $\mathrm{Fe}$ and $\mathrm{Zn}$ nutrition. Spirulina platensis samples were food supplement products that were ready for consumption under different trademarks. Samples were mashed to $\sim 200$ mesh size using mortar agate, then weighed as much as $25 \mathrm{mg}$, put into a 0.273 $\mathrm{mL}$ polyethylene vial, then sealed to close it. The sample is ready to be irradiated. The same thing was done on SRM NIST 1567a Wheat Flour. A standard solution of Fe, Zn, and $\mathrm{Hg}$ drops was prepared, weighing 40, 1, and $0.1 \mu \mathrm{g}$ of Merck and $\mathrm{HgCH}_{3} \mathrm{COO}$ titrisol solutions, respectively. Samples and synthetic standards are ready to be irradiated for 2 hours at the GA reactor Siwabessy, Serpong [34].

\section{Biological samples (human scalp hair)}

In this study, the determination of sample elements using NAA techniques focused on the application of NAA analysis techniques on hair samples to obtain data on the normal concentration of trace elements in a population. In order to ensure the validity of the data, a similar analysis procedure is applied in analyzing the IAEA Human Hair 086 standard material-SRM human hair. Hair sampling is carried out according to the procedure recommended by the IAEA [35]. Hair samples and standard hair material IAEA 086 each weighed as much as $50 \mathrm{mg}$, put in a polyethylene vial measuring 0.273 $\mathrm{mL}$, then sealed by heat. Samples, along with the standard irradiated G.A Siwabessy reactor Serpong was then counted using a gamma ray spectrometer for 10,000 seconds, after cooling it for several weeks. Gamma spectrum analysis and interpretation were performed using Genie-2000 software. With this condition, several results are focused on the toxic elements of $\mathrm{Co}, \mathrm{Cr}$, and $\mathrm{Hg}$ [36].

\section{Geological samples (zircon sand and iron sand)}

For measuring coal fly ash samples, besides NAA method, the Minipal4 EDXRF was used. This EDXRF was equipped with a $\mathrm{Rh}$ tube as an X-ray generator $(9 \mathrm{~W}$ X-ray tube, Max $30 \mathrm{KV}$, max $1 \mathrm{~mA}$ ), 5 filter tubes, silicon detector, and 12 sample trays position with sample spinner. The sample spinner system provides constant rotation during measurement to reduce errors due to homogeneity in sample preparation [37,38]. Characterization of samples using XRF was carried out using the Minipal4 for powder/ solid samples such as coal fly ash samples, and Epsilon5 for air particulate samples. In characterizing the sample using XRF, the parameters that need to be optimized are standard calibrations, secondary targets, measurement conditions, currents, voltages, and measurement times. Changes in these parameters will greatly affect the optimization of the results obtained. Preparation for measurements using XRF does not take much time and special treatment. For powder samples, the sample is dried, homogenized through grinding and sieving, then ready to be placed into the sample holder. For air particulate filter samples, just place them in the sample holder and measurement tray. The optimum condition for this measurement has been optimized, and validation also applied.

\section{RESULTS AND DISCUSSION}

\section{Geological samples (zircon sand and iron sand)}

Uranium (U) and Thorium (Th) measurements were carried out on 26 zircon sand samples in the Kalimantan area and iron sand from Java. The energy used in uranium counting is energy from $\mathrm{Np}$ that is $103.18 ; 228.2$ and $277.7 \mathrm{keV}$, while for thorium, $\mathrm{Pa}$ is used at $312 \mathrm{keV}$ energy [33]. The results of the method validation 
using the National Institute of Science and Technology SRM - NIST Montana Soil 2711a are summarized in Table 3. Validation showed good recovery and precision. The results of $U$ and $T h$ analysis on zircon sand from Kalimantan are shown in Figure 1. The results of $U$ and $T h$ analysis on zircon sand samples indicated that the range of uranium is in the range of 28.6 to $500.8 \mathrm{mg} / \mathrm{kg}$, while for thorium ranges from 19.7 to $612.1 \mathrm{mg} / \mathrm{kg}$ [32]. Most of the sand has $\mathrm{U}$ and Th content above 100 ppm, which is the reference limit of safety guidelines issued by the IAEA, which states that an industrial activity that produces radioactive nature must be taken if the uranium or thorium content is more than $100 \mathrm{ppm}$ [39]. Potential as a source of uranium and thorium in zircon sand must get special handling of regulations regarding the export of zircon sand abroad. The results of this analysis can be a reference in drafting regulations related to zircon sand mining or trading. Meanwhile, zircon content in the sand is in the range of $1.1-31.8 \%$.

The results of $U$ and $T h$ concentrations on iron sand from West Java and East Java are shown in Figure 2. Uranium content in iron sand is in the range of $0.2-5.2 \mathrm{mg} /$ $\mathrm{kg}$ with a mean value of $2.1 \pm 1.3 \mathrm{mg} / \mathrm{kg}$, while thorium levels are in the range of $0.3-3.6 \mathrm{mg} / \mathrm{kg}$ with an average of $1.9 \pm 0.8$ $\mathrm{mg} / \mathrm{kg}$ [40]. Uranium and thorium levels in iron sand are also included as normal levels in the sand and are still below the $100 \mathrm{mg} /$ $\mathrm{kg}$ limit. When compared with the results of measurements of uranium and thorium levels in sand samples in several countries also provide values that are not much

Table 3. Results of IAEA RM Soil-7 and NIST 2711a [32].

\begin{tabular}{cccc}
\hline Element & $\begin{array}{c}\text { Analysis result } \\
(\mathrm{mg} / \mathrm{kg})\end{array}$ & $\begin{array}{c}\text { Certificate value } \\
(\mathrm{mg} / \mathrm{kg})\end{array}$ & Bias $(\%)$ \\
\hline $\begin{array}{c}\text { IAEA RM Soil-7 } \\
\text { Th }\end{array}$ & 15 & 15 & 0.0 \\
NIST 2711a & & \\
Th & 8.18 & 8.2 & -0.2 \\
U & 3.07 & 3.01 & 2.0 \\
\hline
\end{tabular}

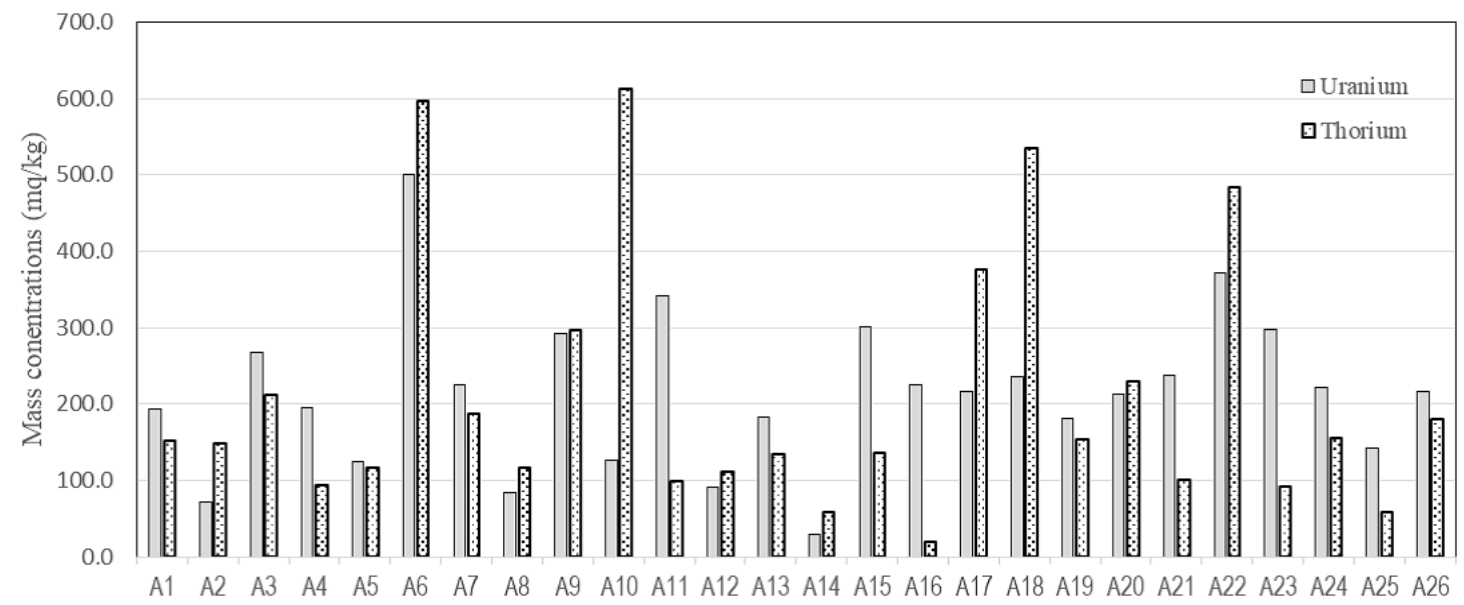

Sample ID

Figure 1. Mass concentration of $\mathbf{U}$ and $\mathbf{T h}$ in zircon sands [32]. 


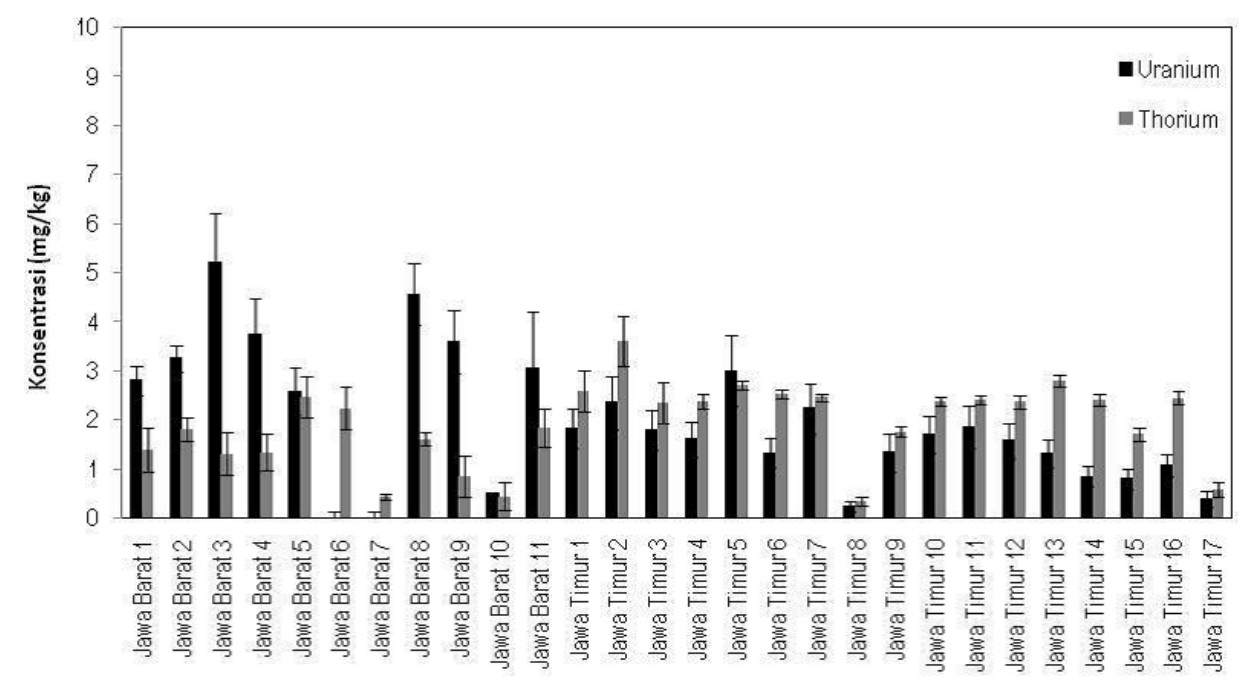

Figure 2. Concentrations of $\mathbf{U}$ and $\mathbf{T h}$ iron sand samples in West Java and East Java [40].

different. Iron content in iron sand samples ranged from 5.4 to $49.5 \%$, which shows that there were several iron sands that have high grades. Through the characterization of iron sand samples, this potential can be further optimized.

\section{Pharmaceutical samples (supplements)}

The results of the characterization of spirulina supplement samples using NAA for $\mathrm{Fe}$ and $\mathrm{Zn}$ are shown in Table 4. Method validation was carried out by SRM Wheat Flour 1568a analysis. The analysis of Fe and Zn elements in SRM samples gives a recovery of 99 and 101\%, respectively [34]. From Table 4, the Fe content of the three spirulina platensis products was varied 647.3; 693.3 and $3320.8 \mathrm{mg} / \mathrm{kg}$, while the $\mathrm{Zn}$ content was $19.2 ; 26.4$ and $43.3 \mathrm{mg} / \mathrm{kg}$. The content of $\mathrm{Fe}$ and $\mathrm{Zn}$ in the first and second product samples is in the normal range for $\mathrm{Fe}$ and $\mathrm{Zn}$ in general commercial spirulina products ranging from $300-1000 \mathrm{mg} / \mathrm{kg}$ and $20-35$ $\mathrm{mg} / \mathrm{kg}$ [34]. Whereas in the third sample for the NAA Fe element $(3321 \mathrm{mg} / \mathrm{kg})$ showed significantly different results and was greater than the other two samples both by the NAA and AAS methods. The results of the sample analysis show a good fit between the NAA and AAS methods, as indicated by the linear regression values for $\mathrm{Fe}$ and $\mathrm{Zn}$, respectively 0.9999 and 0.9860 , respectively. This showed the suitability between the NAA and AAS methods so that they can overcome the limitations/weaknesses of the two methods and can complement each other for analysis [34].

\section{Biological samples (human scalp hair)}

The application of NAA techniques to biological samples is carried out on

Table 4. Fe and $\mathrm{Zn}$ results of suplement samples spirulina plantesis [34].

\begin{tabular}{cccccc}
\hline \multirow{2}{*}{ No. } & Samples & \multicolumn{2}{c}{ Fe $(\mathbf{m g} / \mathbf{k g})$} & \multicolumn{2}{c}{ Zn (mg/kg) } \\
& NAA & AAS & NAA & AAS \\
\hline 1. & Spirulina 1 & $647.3 \pm 8.0$ & $682 \pm 5.5$ & $19.2 \pm 1.0$ & $18.9 \pm 1.3$ \\
2. & Spirulina 2 & $693.3 \pm 7.5$ & $730 \pm 13.5$ & $26.4 \pm 0.7$ & $29.4 \pm 1.2$ \\
3. & Spirulina 3 & $3320.8 \pm 18.3$ & $3256 \pm 18.7$ & $43.3 \pm 1.1$ & $44.9 \pm 2.3$ \\
\hline
\end{tabular}


Table 5. Analysis results of CRM GBW 76101 dan NIES 13 [36,42].

\begin{tabular}{ccccc}
\hline Sample & Element & Analysis results $(\mathrm{mg} / \mathrm{kg})$ & Certificate value $(\mathrm{mg} / \mathrm{kg})$ & \% recovery \\
\hline \multirow{2}{*}{ GBW } & $\mathrm{Co}$ & $0.070 \pm 0.05$ & $0.071 \pm 0.01$ & 98 \\
76101 & $\mathrm{Cr}$ & $0.37 \pm 0,06$ & $0.37 \pm 0,06$ & 99 \\
& $\mathrm{Hg}$ & $0.37 \pm 0.08$ & $0.36 \pm 0.08$ & 101 \\
\hline NIES 13 & $\mathrm{Cr}$ & $4.6 \pm 0.06$ & $4.77 \pm 0.06$ & 96 \\
\hline
\end{tabular}

Table 6. Results of several heavy metals in human hair $[36,42]$.

\begin{tabular}{cccc}
\hline \multirow{2}{*}{ Element } & Traffic service officer & Control & Ratio \\
\cline { 2 - 4 } & Average $(\mathrm{mg} / \mathrm{kg})$ & & \\
\hline $\mathrm{Co}(\mathrm{n}=35)$ & $0.065 \pm 0,01$ & 0.058 & 1.10 \\
$\mathrm{Cr}(\mathrm{n}=32)$ & $0.27 \pm 0.13$ & 0.87 & 3.36 \\
$\operatorname{Hg}(\mathrm{n}=32)$ & $1.41 \pm 0.10$ & 4.72 & 3.23 \\
\hline
\end{tabular}

the characterization of hair samples. This study aimed to determine the impact of occupational exposure to health problems through hair biomarkers of employees of the transportation industry in Bandung. The focus of the activity was the content of toxic elements such as $\mathrm{Co}, \mathrm{Cr}$, and $\mathrm{Hg}$ in the hair samples of the employee [36]. Method validation is done by analyzing the human hair CRM GBW76101 and NIES No. 13. The results of the validation are shown in Table 5. The results of the elemental analysis on the two standard reference materials show good compatibility with the value of the certificate value with \%recovery in the acceptable range under $10 \%$ [36]. This value is within the acceptable range, where for elements in the range of $\sim 10 \mathrm{ppm}$, it is within the limit of $80-115 \%$ recovery [41]. The average and concentration range of the elemental analysis results in hair and control samples are shown in Table 6.

Determination of $\mathrm{Hg}$ with NAA was applied using gamma energy at $279.6 \mathrm{keV}$, but at this energy, there is overlapping with Se at $279.2 \mathrm{keV}$. To overcome it, corrections were made using Se normalization at 400.7 $\mathrm{keV}$ [26]. Whereas for $\mathrm{Co}$ and $\mathrm{Cr}$, there were no interferences on the spectrum. From the results, the concentration of $\mathrm{Cr}$, and $\mathrm{Hg}$ elements in the hair of transportation industry employees have a higher tendency than in control hair. The high $\mathrm{Cr}$ in the hair of employees in the transportation industry is compared with controls in accordance with the results of the study of Ramakhrisna et al. [43].

\section{Environmental samples (coal fly ash and airborne particulate matter)}

4.1. Coal fly ash

Characterization of environmental samples using NAA was applied to coal fly ash samples. Quality control in the form of SRM sample testing with the same matrix is performed on NIST 1633 b coal fly ash SRM samples. The results of the SRM analysis are summarized in Table 7. Figure 3 showed the quality control of coal fly ash analysis.

Comparison analysis of coal fly ash samples with NAA and XRF was resumed in Table 8. It can be seen that there is a good agreement between the NAA and XRF results.

\subsection{Airborne particulate matter}

The results of the characterization of air particulate samples obtained from the Bandung area are summarized, as shown 
Table 7. Analysis results of SRM NIST 1633b coal fly ash [44].

\begin{tabular}{|c|c|c|c|c|c|}
\hline \multirow{2}{*}{$\frac{\text { Element }}{\mathrm{Al}^{*}}$} & \multicolumn{2}{|c|}{ Certificate value (mg/kg) } & \multicolumn{2}{|c|}{ Analysis results (mg/kg) } & \multirow{2}{*}{$\frac{\operatorname{Bias}(\%)}{3,1}$} \\
\hline & 15,05 & $\pm 0,27$ & 15,52 & $\pm 0,73$ & \\
\hline As & 136,2 & $\pm 2,6$ & 135,7 & $\pm 2,3$ & 0,4 \\
\hline $\mathrm{Ce}$ & & 190 & 182 & $\pm 10,2$ & 4,2 \\
\hline $\mathrm{Co}$ & & 50 & 51,3 & \pm 3 & 2,6 \\
\hline $\mathrm{Cr}$ & 198,2 & $\pm 4,7$ & 192,3 & $\pm 9,4$ & 3,0 \\
\hline $\mathrm{Fe}^{*}$ & 7,78 & $\pm 0,23$ & 7,74 & $\pm 0,23$ & 0,5 \\
\hline $\mathrm{K}^{*}$ & 1,950 & $\pm 0,030$ & 1,980 & $\pm 0,037$ & 1,5 \\
\hline $\mathrm{La}$ & & 94 & 88,4 & $\pm 3,1$ & 6,0 \\
\hline $\mathrm{Mn}$ & 131,8 & $\pm 1,7$ & 131 & $\pm 6,0$ & 0,6 \\
\hline $\mathrm{Na}^{*}$ & 0,201 & $\pm 0,003$ & 0,221 & $\pm 0,003$ & 9,5 \\
\hline $\mathrm{Sc}$ & & 41 & 40,8 & $\pm 0,6$ & 0,5 \\
\hline $\mathrm{Sm}$ & & 20 & 19,0 & $\pm 0,1$ & 5,0 \\
\hline $\mathrm{Ti}^{*}$ & 0,791 & $\pm 0,014$ & 0,788 & $\pm 0,118$ & 0,4 \\
\hline $\mathrm{V}$ & 295,7 & $\pm 3,6$ & 283,6 & $\pm 28,1$ & 4,1 \\
\hline
\end{tabular}

Note: * in percent

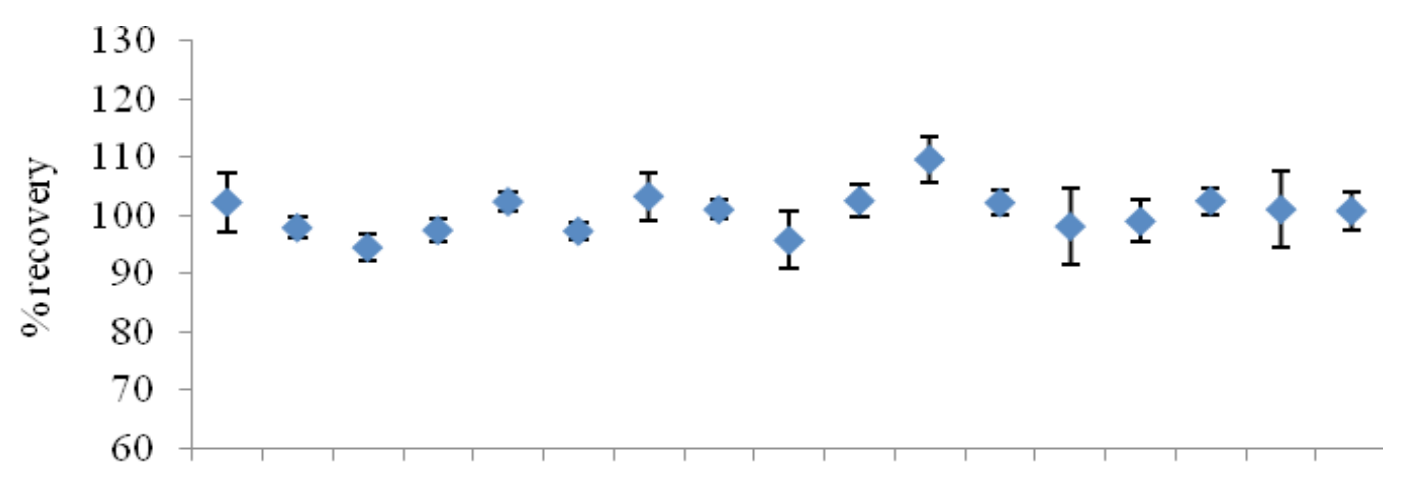

K Ca Ti V Cr Mn Fe Ni Cu Zn Rb Sr Pb Al Co Se Sm

Jnsur

Figure 3. The accuracy of the results of the SRM 1633b Coal Fly Ash analysis using the XRF method [44].

Table 8. Comparison results of NAA and XRF in coal fly ash samples [44].

\begin{tabular}{ccccccc}
\hline Element & \multicolumn{3}{c}{ NAA } & \multicolumn{3}{c}{ XRF } \\
\hline $\mathrm{Al}(\%)$ & 11,7 & $\pm 5,1$ & 12,2 & \pm & 0,91 \\
$\mathrm{Fe}(\%)$ & 9,02 & $\pm 0,29$ & 8,99 & \pm & 0,12 \\
$\mathrm{Ca}(\%)$ & 3,96 & $\pm 0,37$ & 3,79 & \pm & 0,04 \\
$\mathrm{Ti}(\%)$ & 0,52 & $\pm 0,08$ & 0,48 & \pm & 0,014 \\
$\mathrm{~K}(\%)$ & 0,65 & $\pm 0,08$ & 0,65 & \pm & 0,038 \\
$\mathrm{Co}(\mathrm{mg} / \mathrm{kg})$ & 60,3 & $\pm 3,6$ & 62,7 & \pm & 6,9 \\
$\mathrm{Cr}(\mathrm{mg} / \mathrm{kg})$ & 112 & $\pm 9,3$ & 126 & \pm & 10 \\
$\mathrm{~V}(\mathrm{mg} / \mathrm{kg})$ & 117 & \pm 6 & 113 & \pm & 7 \\
$\mathrm{Zn}(\mathrm{mg} / \mathrm{kg})$ & 256 & \pm 19 & 254 & \pm & 3 \\
\hline
\end{tabular}

in Figure 4. From all elements detected in the $\mathrm{PM}_{2.5}$ sample (particulate matter with an aerodynamic diameter less than $2.5 \mu \mathrm{m}$ ), it is shown that the elements $\mathrm{Na}, \mathrm{Cl}, \mathrm{Al}$,
$\mathrm{Si}, \mathrm{S}, \mathrm{K}, \mathrm{Ca}$, and Fe are the elements with the dominant concentration in the samples. Other trace elements such as $\mathrm{V}, \mathrm{Cr}, \mathrm{Cu}, \mathrm{Ni}$, $\mathrm{Hg}$, and $\mathrm{Pb}$ can be detected properly using 
PIXE. These elements play a sufficient role that can indicate sources of anthropogenic pollution such as industries, chimneys, or certain metal industries.

Comparison of the PIXE and NAA methods was also carried out on the same sample, where a ratio of $0.97 \pm 0.01$ with a coefficient of R $2=0.99$ was obtained (Figure 5) [24]. This result shows a very good suitability even if the analysis is done in a different laboratory. Several other studies also confirm that PIXE gave very significant results in the analysis of air particulate samples $[1,20,28]$.

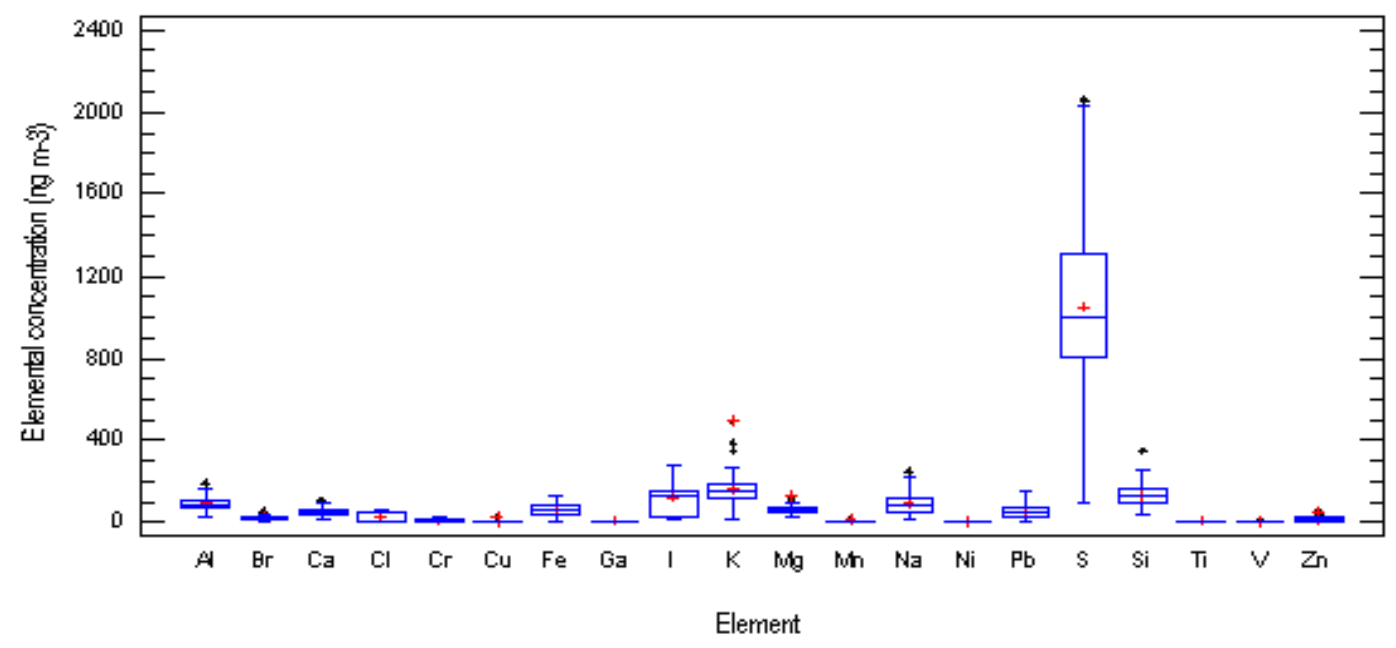

Figure 4. Whisker plot of several elements in the APM by PIXE [45]

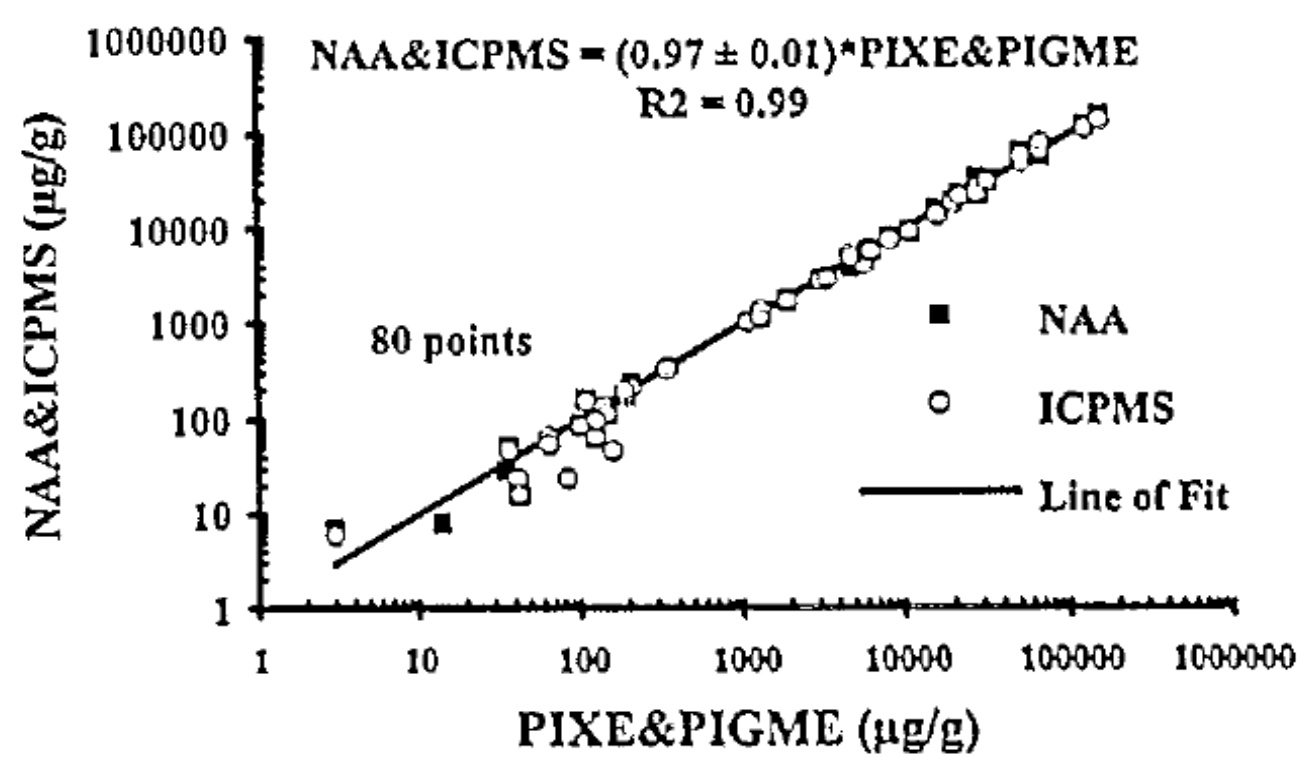

Figure 5. Comparison NAA, ICPMS and PIXE-PIGME [24] 


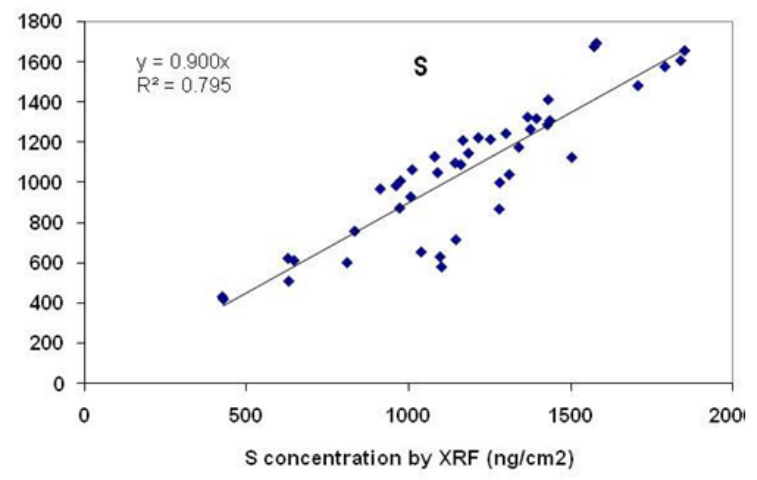

(a)

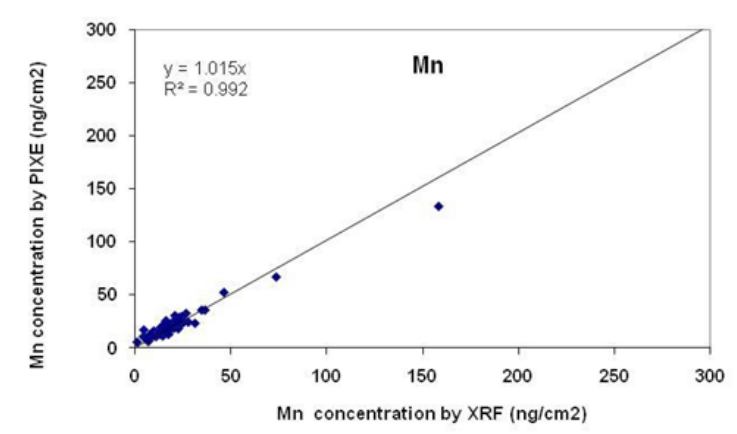

(c)

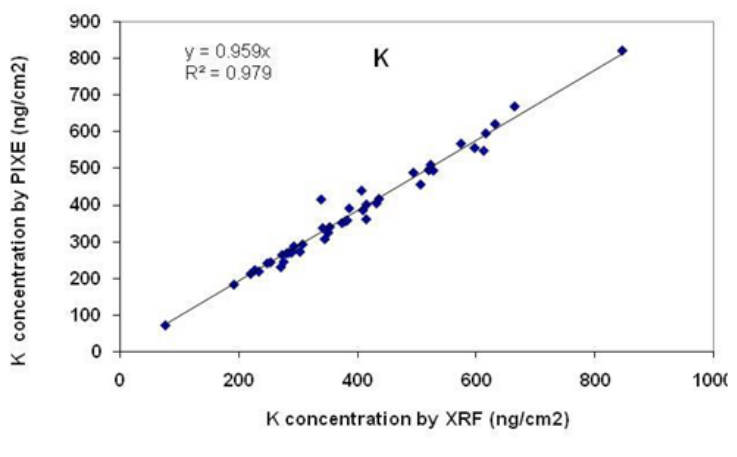

(b)

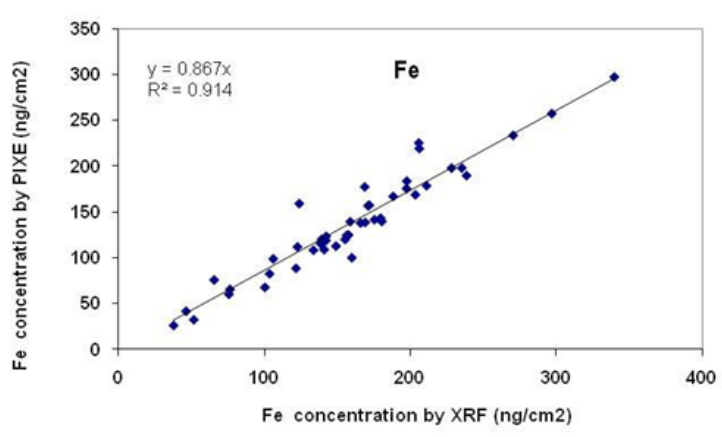

(d)

Figure 6. Comparison of results on S, K, Mn and Fe by XRF and PIXE [46]

To guarantee the results of the XRF test, the results were compared with PIXE. Comparative results for several elements are shown in Figure 6. PIXE measurements were carried out at Geological Nuclear Science, New Zealand. It can be seen that for the elements $\mathrm{S}, \mathrm{K}, \mathrm{Fe}$, and $\mathrm{Mn}$ there is a good match between the XRF and PIXE techniques.

\section{CONCLUSION}

The application of NATs in particularly NAA, PIXE, and XRF on various samples, validation, and comparison with other methods, showed that NAT is an analytical technique that has good and reliable accuracy and precision in the characterization of the various sample matrix. This capability is good in terms of excellence, multi-element, good detection limits, which will be the answer to the challenges of the need for characterization of samples in various fields. The data obtained is needed in the first step of each related research to be followed by further research in the form of interpretation, study, and policy-making and appropriate strategy in overcoming the existing problems. The end-users who need and utilize this characterization capability are not only the government but academics from various universities, researchers from private institutions, industrial, regional R\&D institutions, and many others. The development of NAT, especially for PIXE, which is still not available yet in Indonesia, is encouraged and promising to be utilized in several fields of research.

\section{ACKNOWLEDGMENT}

This research was supported by a grant from the Indonesian government through the Center of Applied Nuclear Science 
and Technology, National Nuclear Energy Agency. The main contributor of this paper is Diah Dwiana, and other authors contributed as member contributors in each part to the research design, acquisition of data, counting, and analysis.

\section{REFERENCES}

1. Watson JG. X-Ray Fluorescence Analysis Of Ambient Air Samples. 2014;(January 1999).

2. Kučera J, Kameník J, Havránek V. Hair elemental analysis for forensic science using nuclear and related analytical methods. Forensic Chem. 2018;7:65-74.

3. Hernández F, Bakker J, Bijlsma L, de Boer J, Botero-Coy AM, Bruinen de Bruin Y, et al. The role of analytical chemistry in exposure science: Focus on the aquatic environment. Chemosphere. 2019;222:564-83.

4. Sajtos Z, Herman P, Harangi S, Baranyai E. Elemental analysis of Hungarian honey samples and bee products by MPAES method. Microchem J [Internet]. 2019;149(February):103968. Available from: $\quad$ https://doi.org/10.1016/j. microc.2019.103968

5. Dalipi R, Borgese L, Tsuji K, Bontempi E, Depero LE. Elemental analysis of teas, herbs and their infusions by means of total reflection X-ray fluorescence. J Food Compos Anal. 2018;67(January):128-34.

6. Naidu BG, Sarita P, Naga Raju GJ, Tiwari MK. Multivariate analysis of trace elemental data obtained from blood serum of breast cancer patients using SRXRF. Results Phys [Internet]. 2019;12(September 2018):67380. Available from: https://doi.org/10.1016/j. rinp.2018.12.020

7. Uo M, Wada T, Sugiyama T. Applications of $\mathrm{X}$-ray fluorescence analysis (XRF) to dental and medical specimens. Jpn Dent Sci Rev [Internet]. 2015;51(1):2-9. Available from: http://dx.doi.org/10.1016/j.jdsr.2014.07.001

8. Santos RF, Cruz SM, Krzyzaniak SR, Duarte FA, Mello PA, Flores EMM. Trace metal impurities determination in high-purity polyimide by plasma-based techniques. Microchem J [Internet]. 2019; 146(November
2018):492-7. Available from: https://doi. org/10.1016/j.microc.2019.01.039

9. Sudersanan M. Role of analytical techniques for characterisation of advanced and high purity materials. Prog Cryst Growth Charact Mater. 2002;44(3):189-94.

10. Kumar M, Bhatia R, Rawal RK. Applications of various analytical techniques in quality control of pharmaceutical excipients. J Pharm Biomed Anal [Internet]. 2018;157:122-36. Available from: https://doi.org/10.1016/j. jpba.2018.05.023

11. Dhara S, Misra NL. Elemental characterization of nuclear materials using total reflection X-ray fluorescence spectrometry. TrAC - Trends Anal Chem [Internet]. 2019;116:31-43. Available from: https://doi.org/10.1016/j.trac.2019.04.017

12. Kurniawati S, Lestiani DD, Damastuti E, Santoso M. The selenium content of Tempeh in Indonesia and its potential contribution to the dietary selenium requirements for adults. J Food Compos Anal [Internet]. 2019;82(May):103222. Available from: https://doi.org/10.1016/j.jfca.2019.05.005

13. Martins FCOL, Sentanin MA, De Souza D. Analytical methods in food additives determination: Compounds with functional applications. Food Chem [Internet]. 2019;272(April 2018):732-50. Available from: https://doi.org/10.1016/j. foodchem.2018.08.060

14. Mikulewicz M, Chojnacka K, Gedrange T, Górecki $\mathrm{H}$. Reference values of elements in human hair: A systematic review. Environ Toxicol Pharmacol [Internet]. 2013;36(3):1077-86. Available from: http:// dx.doi.org/10.1016/j.etap.2013.09.012

15. Chitturi R, Baddam VR, Prasad L, Prashanth L, Kattapagari K. A review on role of essential trace elements in health and disease. J Dr NTR Univ Heal Sci. 2015;4(2):75.

16. Tang M, Xu C, Lin N, Liu K, Zhang Y, Yu $\mathrm{X}$, et al. Lead, mercury, and cadmium in umbilical cord serum and birth outcomes in Chinese fish consumers. Chemosphere [Internet]. 2016;148:270-5. Available from: $\quad$ http://dx.doi.org/10.1016/j. chemosphere.2016.01.058 
17. Vinceti M, Filippini T, Mandrioli J, Violi F, Bargellini A, Weuve J, et al. Lead, cadmium and mercury in cerebrospinal fluid and risk of amyotrophic lateral sclerosis: A case-control study. J Trace Elem Med Biol [Internet]. 2017;43:121-5. Available from: http:// dx.doi.org/10.1016/j.jtemb.2016.12.012

18. Bornhorst J, Kipp AP, Haase H, Meyer S, Schwerdtle T. The crux of inept biomarkers for risks and benefits of trace elements. TrAC - Trends Anal Chem. 2018;104:183-90.

19. Akahoshi N, Anan Y, Hashimoto Y, Tokoro N, Mizuno R, Hayashi S, et al. Dietary selenium deficiency or selenomethionine excess drastically alters organ selenium contents without altering the expression of most selenoproteins in mice. J Nutr Biochem [Internet]. 2019;69:120-9. Available from: https://doi.org/10.1016/j. jnutbio.2019.03.020

20. Santoso M, Lestiani DD, Mukhtar R, Hamonangan E, Syafrul H, Markwitz A, et al. Preliminary study of the sources of ambient air pollution in Serpong, Indonesia. Atmos Pollut Res [Internet]. 2011;2(2):1906. Available from: http://linkinghub.elsevier. com/retrieve/pii/S1309104215305031

21. Brown RJC, Milton MJT. Analytical techniques for trace element analysis: An overview. TrAC - Trends Anal Chem. 2005;24(3 SPEC. ISS.):266-74.

22. Bode P. Chapter 1 Nuclear Analytical Techniques for Environmental Research. Encycl Atmos Sci [Internet]. 2001;4(i):116. Available from: http://cdiac.esd.ornl. gov/oceans/GLODAP/glodap_pdfs/ Thermohaline.web.pdf

23. William D E, Diane E V. Radiochemistry and Nuclear Methods of Analysis. Anal Chim Acta. 1994;288(3):279-80.

24. Cohen DD, Bailey GM, Kondepudi R. Elemental analysis by PIXE and other IBA techniques and their application to source fingerprinting of atmospheric fine particle pollution. Nucl Instruments Methods Phys Res Sect B Beam Interact with Mater Atoms. 1996;109-110:218-26.

25. Glascock M.D. Overview of Neutron Activation Analysis [Internet]. [cited 2019
Feb 11]. Available from: http://archaeometry. missouri.edu/naa_overview.html

26. IAEA International Atomic Energy Agency. Sampling and Analytical Methodologies for Instrumental Neutron Activation Analysis of Airborne Paniculate Matter. 1992;(4).

27. Trompetter, W., Lestiani, D.D., Davy, P., Barry, B., Markwitz A. Ion Beam Analysis results of air particulate matter collected in Indonesia (2006-2009). 2010.

28. Ivošević T, Mandić L, Orlić I, Stelcer E, Cohen DD. Comparison between XRF and IBA techniques in analysis of fine aerosols collected in Rijeka, Croatia. Nucl Instruments Methods Phys Res Sect B Beam Interact with Mater Atoms. 2014;337:83-9.

29. Peter B. Theory of XRF, Getting acquainted with the principles. Almelo, Netherland: PANalytical BV; 2003.

30. Peter B. Theory of XRF, 2nd ed. Almedo, Amsterdam: PANalytical BV; 2006.

31. Kist AA. Nuclear analytical methods in the life sciences. J Anal Chem. 1996;51(2):802.

32. Lestiani, Dwiana D, Kurniawati S, Kusmartini I, Adventini N, Yatu Niken Syahfitri W, Santoso M. Assesment of Environmental Safety Related Radioactivity Exposure In Zircon Sand. J Ecolab. 2019;13(1):11-8.

33. Tiwari S, Nair AGC, Acharya R, Reddy AVR, Goswami A. Analysis of Uranium Bearing Samples for Rare Earth and Other Elements by $\mathrm{k} 0$-Based Internal Monostandard INAA Method. J Nucl Radiochem Sci. 2007;8(1):25-30.

34. Syahfitri WYN, Kurniawati S, Santoso M. Komparasi Metode Analisis Aktivasi Neutron Dan Spektrometri Serapan Atom Pada Penentuan Unsur Fe, Zn dan Hg dalam Spirulina Platensis. Proceeding Natl Semin Neutron Act Anal. 2010;232-41.

35. Pozebon D, Scheffler GL, Dressler VL. Elemental hair analysis: A review of procedures and applications. Anal Chim Acta. 2017;992:1-23.

36. Damastuti E, Adventini N, Syahfitri WYN, Kurniawati S, Lestiani DD, Santoso M. Assessment of heavy metals on 
occupationally exposed workers from hair analysis. Atom Indones. 2017;43(3).

37. Kurniawati S, Kusmartini I, Adventini N, Lestiani DD. Applicability of ED-XRF Spectrometer for Sediment Analysis. In: Nasional Seminar Nuclear Analytical Technique. Center for Applied Nuclear Science and Technology; 2012. p. 152-8.

38. Oreščanin V, Mikelić IL, Mikelić L, Lulić S. Applicability of MiniPal 4 compact EDXRF spectrometer for soil and sediment analysis. X-Ray Spectrom [Internet]. 2008 Sep 1;37(5):508-11. Available from: http:// dx.doi.org/10.1002/xrs.1079

39. IAEA International Atomic Energy Agency. Safety Reports Series no. 51, Radiation Protection and NORM Residue Management in the Zircon and Zirconia Industries. Vienna; 2007. 162 p.

40. Kusmartini I, Lestiani DD, Kurniawati S, Syahfitri WYN. Containing Status of Uranium and Thorium in Iron Sand of West Java. In: National Seminar on Nuclear Analytical Techniques. 2013. p. 68-73.

41. AOAC. AOAC International Guidelines for Single Laboratory Validation (2002). 2002.

42. Damastuti E, Yatu W, Shyahfitri N, Adventini N. Karakterisasi Unsur Dalam Rambut Petugas Dllajr Untuk. 2011;25-6.
43. Ramakhrisna, V.V.S., Singh, V., Garg A. Occupational eksposure amongst locomotive shed workers and welders using neutron activation analysis of scalp hair. Sci Total Enviroment. 1996;192:259-67.

44. Lestiani DD, Santoso M. Enhancing Laboratory Analytical Capability for Composition Analysis in Analysis in Airborne Particulate Matters By Energy Dispersive X-Ray. In: National Seminar on Nuclear Analytical Techniques. 2012. p. 99-106.

45. Santoso M, Hopke PK, Hidayat A, Diah Dwiana L. Sources identification of the atmospheric aerosol at urban and suburban sites in Indonesia by positive matrix factorization. Sci Total Environ. 2008;397(1-3).

46. Santoso M, Lestiani DD. IAEA XRF Newsletter: $X$ ray Fluorescence in Member States. 2014. 